\title{
Emergent arboviruses in Brazil
}

\author{
Arboviroses emergentes no Brasil
}

\author{
Luiz Tadeu Moraes Figueiredo ${ }^{1}$
}

\begin{abstract}
Brazil is a large tropical country $\left(8,514,215 \mathrm{~km}^{2}\right)$ with 185,360,000 inhabitants. More than one third of its territory is covered by tropical forests or other natural ecosystems. These provide ideal conditions for the existence of many arboviruses, which are maintained in a large variety of zoonotic cycles. The risk that new arboviruses might emerge in Brazil is related to the existence of large, densely populated cities that are infested by mosquitoes such as Culex and the highly anthropophilic Aedes aegypti. Infected humans or animals may come into these cities from ecological-epidemiological settings where arbovirus zoonoses occur. This study analyzes the risk of emergence of the alphaviruses Mayaro, Venezuelan equine encephalitis, Eastern equine encephalitis and Chikungunya; the flaviviruses yellow fever, Rocio, Saint Louis encephalitis and West Nile; and the orthobunyavirus Oropouche.
\end{abstract}

Key-words: Emergent arboviruses in Brazil. Alphavirus. Flavivirus. Orthobunyavirus.

\section{RESUMO}

O Brasil é país tropical de grande extensão territorial $\left(8.514 .215 \mathrm{~km}^{2}\right)$ e com 185.360.000 habitantes. Mais de 1/3 deste território é recoberto por florestas tropicais ou outros ecossistemas naturais com condições ideais para a ocorrência de diversas arboviroses as quais são mantidas em uma grande variedade de ciclos zoonóticos. O risco para a emergência de novos arbovirus no Brasil relaciona-se à existência de cidades grandes, populosas e infestadas por mosquitos Culex bem como o altamente antropofílico Aedes aegypti. Nas cidades poderiam ser introduzidos seres humanos ou animais infectados oriundos de sítios eco-epidemiológicos onde existem zoonoses arbovíricas. Neste trabalho, analisa-se o risco de emergência dos alphavirus Mayaro, da encefalite eqüina venezuelana, da encefalite eqüina do leste e Chikungunya, dos flavivirus, da febre amarela, Rocio, da encefalite de Saint Louis e do Nilo Ocidental, e do orthobunyavirus Oropouche.

Palavras-chaves: Arbovírus emergentes no Brasil. Alphavirus. Flavivirus. Orthobunyavirus.

Arboviruses (arthropod-borne viruses) are zoonotic RNA viruses (Togaviridae, Flaviviridae, Bunyaviridae, Reoviridae and Rhabdoviridae) that are maintained in nature in complex cycles involving arthropod vectors (mostly mosquitoes and ticks) that, after infection, transmit these microorganisms by feeding on animal blood (mostly from birds and mammals). The cycle is completed by infection of new arthropods that feed upon viremic animals. Vertical transmission can also occur, by a transovarial route, in which the parent arthropod passes the arbovirus to its progeny. Recently, large portions of Flaviviridae genomes were observed within Aedes mosquitoes, thus giving the idea that these latent viruses might emerge from there ${ }^{8}$. However, this is a supposition that still requires confirmation.

The emergence and reemergence of arboviruses are natural phenomena related to species evolution and adaptation. During the infection of multiple and distinct organisms, the virus may be selected by the host, which may produce more virulent or better-adapted strains. RNA viruses have high error rates that can produce genomic mutations during RNA transcription, caused by mistakes made by the viral polymerase. The population that results is often referred to as a quasispecies. Another cause of RNA virus mutation is genome recombination or drifting, which can occur if there is simultaneous infection of the animal by more than one virus of the same family or genus?.

Ecological changes produced by man may increase vector prevalence, create new reservoirs or induce arboviruses to adapt to new maintenance cycles. Furthermore, because arboviruses can travel large distances and move into new countries or even continents, they have the potential for pandemic spreading.

Brazil is a large tropical country $\left(8,514,215 \mathrm{~km}^{2}\right)$ with a population of $185,360,000$ in 2006 , mostly living in large cities in the northeast and southeast of the country. Despite the continually high rate of deforestation, more than one third of Brazilian territory is still covered by rainforests and other natural

1. Centro de Pesquisa em Virologia, Faculdade de Medicina de Ribeirão Preto, Universidade de São Paulo, Ribeirão Preto, SP, Brazil.

Address to: Prof. Luiz Tadeu Moraes Figueiredo. Centro de Pesquisa em Virologia/FMRP/USP. Av. Bandeirantes 3900, $14049-900$ Ribeirão Preto, SP.

Tel: 55 16 3602-3271, Fax: 5516 3633-6695.

e-mail: ltmfigue@fmrp.usp.br

Recebido para publicação em 20/7/2006

Aceito em 19/3/2007 
ecosystems, which have an extremely diverse flora and fauna (IBGE, Brazilian Government, 1996). These ecosystems provide ideal conditions for the existence of many arboviruses, which are maintained in a large variety of zoonotic cycles. In fact, more than 200 different arbovirus species have been isolated in Brazil, and about 40 of them cause human diseases ${ }^{25}$.

The risk that new arboviruses might emerge in Brazil is related to the existence of large, densely populated cities that are infested by mosquitoes such as Culex and the highly anthropophilic Aedes aegypti. Infected humans or animals may come into these cities from ecological-epidemiological settings where arbovirus zoonoses occur.

Although recognizing that dengue is today the most important emerging arboviral disease in Brazil, it was not the intention of the present article to undertake an analysis on dengue. Rather, the intention was to focus on other arboviruses that have been less discussed in the medical literature. Forecasts and related data on the emergence or reemergence of nine arboviruses are presented here. The arboviruses presented from the Alphavirus genus (Togaviridae) are: Mayaro (MAYV), Venezuelan equine encephalitis (VEEV), Eastern equine encephalitis (EEEV) and Chikungunya (CHIKV), which are 70-nm enveloped viruses that have an icosahedral capsid and single-stranded positivepolarity RNA of 11.8 kilobases, including eight genes, five of them from structural proteins (capsid, E3, E2, 6K and E1) ${ }^{19}$. The arboviruses presented from the Flavivirus genus (Flaviviridae) are: yellow fever virus (YFV), the Japanese encephalitis complex viruses (Rocio; ROCV), Saint Louis encephalitis (SLEV) and West Nile (WNV), which are 60-nm enveloped viruses that have an icosahedral capsid and single-stranded positive-polarity RNA of 10.5 kilobases, including ten genes, three of them from structural proteins $(\mathrm{C}, \mathrm{prM} \text { and } \mathrm{E})^{5}$. The arbovirus presented from the Orthobunyavirus genus (Bunyaviridae), Simbu serogroup, is the Oropouche virus (OROV), which is an 80 to 120 -nm enveloped virus that has three single-stranded negative-sense RNA segments that are termed large (L), medium (M) and small $(\mathrm{S})^{26}$.

The Mayaro virus has been responsible for outbreaks of acute febrile illness in the Amazon region and on the Central Plateau of Brazil, as well as in other South American countries (Peru, Bolivia and Venezuela). MAYV strikes people who work or live in the Amazon forest. The three to five-day course of illness is characterized by fever, headache, myalgia, rash, prominent pain in the large joints and, less frequently, arthritis. Convalescence from MAYV fever usually takes a couple of weeks $^{24}$. The arboviral cycle for MAYV is similar to the cycle for sylvan yellow fever and includes monkeys as reservoirs and tree canopy Haemagogus mosquitoes as vectors ${ }^{34}$. In fact, 18 years ago, MAYV fever outbreaks were followed by the appearance of yellow fever cases in Santa Cruz de la Sierra, Bolivia $^{13} 33$. MAYV also infects birds and two of these infected animals were found recently in southern Brazil (Araujo AA: personal communication, 2005).

Considering that MAYV can be transmitted by Aedes mosquitoes, this virus could move to cities in viremic birds or human travelers (recently, three fishermen were reported infected in São Paulo State) and could adapt to a new cycle that could involve man as reservoir ${ }^{731}$. Finally, airborne transmission of MAYV, which was previously reported as the causative agent for an accidental laboratory infection, could potentially become a natural transmission route, thereby facilitating spreading of the virus in large epidemics ${ }^{18}$.

Venezuelan equine encephalitis virus subtype IF occurs in southeastern Brazil and causes febrile illness and diarrhea in individuals who visit the Atlantic rain forest ${ }^{16}$. VEEV has also been isolated in the Amazon region ${ }^{25}$. The $1 \mathrm{C}$ subtype of VEEV occurs endemically in Colombia and Venezuela and is a cause of epizootics and epidemics. VEEV IC is maintained in a cycle involving rodents, birds and Culex mosquitoes that may occasionally transmit the virus to humans ${ }^{39}$. However, this virus can adapt to a new cycle that induces secondary amplification involving equines and some mosquito species (Aedes, Psorophora, Mansonia and Deinocerites). The adaptation of enzootic strains requires mutations that allow for efficient production of viremia. In fact, Ser substitution for Asn in the E2 envelope glycoprotein gene is the major determinant of increased infectivity of VEEV IC to both equines and mosquito vectors ${ }^{4}$. The 1969-1972 VEEV IC epidemic/epizootic, which was one of the largest that has ever occurred, started in Colombia and spread northwards through Central America, to Mexico and the southern United States. It caused tens of thousands of human cases with hundreds of deaths. Thousands of equines also died, with important economic losses ${ }^{4}$. In 1995, an outbreak of VEEV 1C affected individuals in Venezuela and Colombia, causing 1,300 human encephalitis cases with a $10-15 \%$ case fatality rate ${ }^{22}$.

Communications and trading between Brazil and the northern countries of South America have increased over the last few years. Thus, a road has been constructed from Manaus (Brazil) to Caracas (Venezuela) and this has significantly increased trade between the two countries. However, this new road may also offer a new route for VEEV 1C to spread in future epizootics/epidemics. Furthermore, the scenario of such outbreaks could be worsened by Aedes albopictus, a rural mosquito that has expanded fast since its first detection in 1986 and is now reported in all regions of Brazil. Aedes albopictus has been found to be susceptible to VEEV IC and could become a vector for $\mathrm{it}^{11}$.

Eastern equine encephalitis virus has been isolated in the northern, northeastern and southeastern regions of Brazil, where it has caused equine epizootics ${ }^{37}$. EEEV is a causative agent for severe human encephalitis in North America ${ }^{38}$. In Brazil, only one human case of EEEV encephalitis has been reported and this was more than fifty years ago. Three lineages of EEEV have been recognized in South America and all of them are found in Brazil, where the virus is maintained in a cycle involving wild birds and rodents as reservoirs, and with Culex pedro $i$ as the enzootic and Aedes taeniorbynchus as the epizootic vector $^{3}{ }^{37}$. Ten years ago, EEEV was isolated from mosquitoes captured during a dengue outbreak in the northeast, in Ceará State (Rosa APAT, personal communication, 2004). The three viral lineages circulate practically throughout country and have been associated with sporadic small outbreaks of encephalitis in horses. 
In 2003, two horses with EEEV encephalitis were reported in the southeast ${ }^{2}$. There are concerns that a more virulent form of EEEV could be selected or become well adapted to cycles that allow its emergence as an important veterinarian and human public health problem in Brazil.

Chikungunya virus is an African alphavirus that belongs to the same SF genotype as MAYV. CHIKV, which was first described in 1952, has spread over the Indian Ocean islands (Reunion, Madagascar, Mauritius, Seychelles and Mayotte) since 2005, causing explosive large outbreaks of acute febrile illness with prominent arthralgia and some cases of meningoencephalitis ${ }^{30}$ (WHO report on outbreaks of Chikungunya, 2005-2006). To date, no death has been directly attributed to acute CHIKV infection. Like dengue, CHIKV is transmitted to humans by the bites of infected Aedes aegypti and A. albopictus, thus forming virus reservoirs. Mother-to-child transmission of the virus has also been reported. Considering that an outbreak of CHIKV has been recently reported in Andhra Pradesh State (India) and that imported cases of CHIKV fever were reported in many European countries during 2006, this viral disease represents a worrisome emerging worldwide health problem (WHO report on outbreaks of Chikungunya, 2005-2006). Thus, CHIKV could be introduced into large Brazilian cities that are infested with Aedes aegypti and A. albopictus, by human or mosquito travelers.

The yellow fever virus is the causative agent for severe hepatitis, followed by hemorrhagic fever in about $10 \%$ of infected individuals ${ }^{34}$. Based on the high genome similarity between Western African and South American isolates, it has been suggested that YFV, which was originally from Africa, was introduced into the Americas on more than one occasion during the last 500 years $^{6}$. YFV was introduced into Brazil by slave-trading ships from Africa and other trading ships from North America and the Caribbean. YFV caused large outbreaks along the coast of Brazil, particularly during the $19^{\text {th }}$ century. It became a severe public health problem in Rio de Janeiro, where the virus killed about 50,000 people between 1850 and 1909, and was only definitively eradicated in $1930^{14}$.

It has been hypothesized that, after reaching the Americas and causing notable urban outbreaks, YFV adapted to a sylvan cycle involving primates and Haemagogus mosquitoes from the tree canopy as its vectors ${ }^{28}$. From 1950 onwards, YFV became a mobile zoonosis that now circulates in the Brazilian Amazon, Chaco and Central Plateau regions. The traffic of virus variants across large geographic areas via the migration of infected people may be an important mechanism for virus dispersal ${ }^{37}$. After 1999, monkey epizootics and human outbreaks of YFV began to occur close to highly populated regions of southeastern Brazil. Outbreaks occurred in Goiás State in 1999 and in Minas Gerais State, close to the City of Belo Horizonte, in 2001, 2004 and 2005. The virus has infected ecotourists, fishermen, agricultural workers and truck drivers (Brazilian Ministry of Health, 2005).

The urban YFV cycle has not been reported in Brazil since $1942^{14}$. However, urban transmission of YFV probably occurred close to the Brazilian border, in Santa Cruz de la Sierra (Bolivia) less than 10 years ago ${ }^{33}$. Thus, there is a risk of urbanization of
YFV through movements of infected people into cities where Aedes aegypti is disseminated ${ }^{15}$.

To fight YFV there is a powerful weapon: a vaccine composed of the attenuated and highly immunogenic 17D YFV. This vaccine has been used in Brazil for 65 years and more than 212 million vaccine doses have been administered. After 1999, in order to control sylvan YFV outbreaks, it was decided to vaccinate the whole Brazilian population. About sixty million people were vaccinated up to 2001, when three immunocompetent individuals died as a consequence of severe disease caused by $17 \mathrm{D} \mathrm{YFV}^{36}$. These deaths forced the Brazilian Ministry of Health to stop mass vaccination. However, the 17D YFV vaccine is part of the national program for children older than six months and for travelers visiting endemic yellow fever areas, which cover more than half of Brazil (Brazilian Ministry of Health, 2005).

The Rocio virus was firstly isolated in 1975, from a fatal case that occurred during an encephalitis outbreak in a limited area of the Atlantic forest, in the Ribeira Valley, São Paulo State ${ }^{20}$. The outbreak started in 1973 and finished in 1980. About 1000 encephalitis cases were reported, with a $10 \%$ case fatality rate, and among the survivors, 200 suffered motility or equilibrium sequelae ${ }^{17}$.

On the basis of virus isolation and serology data, ROCV is believed to be maintained in a cycle in which wild birds, including some migratory species, are the reservoirs and Aedes and Psorophora mosquitoes are the vectors ${ }^{31}$. It is still unknown how this new flavivirus appeared in 1973 and disappeared seven years later from the Ribeira Valley. However, the presence of neutralizing antibodies for ROCV has been detected in people living in rural areas of southeastern and northeastern Brazil ${ }^{12,29}$. Likewise, in 2004 , two birds were found presenting antibodies to ROCV in the southern region (Araujo AA: personal communication, 2005). It is possible that this virus circulates in distinct regions of Brazil and the reemergence of ROCV with ensuing severe encephalitis outbreaks represents a permanent threat.

The Saint Louis encephalitis virus is widely distributed in the Americas, from Canada to Argentina. The first Brazilian SLEV isolate was obtained in 1960 from a pool of Sabethes belisarioi captured along the Belém-Brasilia highway. The reservoirs for SLEV are wild birds, primates, sloths, armadillos and marsupials and Culex declarator and C. coronator are its vectors ${ }^{37}$. Longdistance migratory birds probably disperse the virus across the Americas, as observed with the Brazilian SLEV 68 strain, which, despite where it was isolated, clustered phylogenetically with North American strains ${ }^{32}$. Along with the extensive spreading of SLEV across the Americas, there have been viral mutations caused by simultaneous infections with distinct strains, as observed in the Guatemala 69 isolate, which showed a combination of Argentinean and North American nucleotide sequences in the E protein gene ${ }^{32}$. In 2004, SLEV was isolated in southeastern Brazil from a patient with acute febrile illness who presented severe headache and had been thought to have dengue ${ }^{27}$. Analysis of this strain showed that it was phylogenetically distinct from all previously characterized Brazilian SLEV, and that it clustered with an Argentinean strain (Santos CL: personal communication, 2005). 
On the basis of a close genetic relationship, the WNV strain isolated in New York in 1999 had probably moved from the Middle East to the Americas. In North America, WNV has caused huge encephalitis epidemics and horse epizootics. It is remarkable how WNV, a virus from the Old World, has become adapted to an unprecedented American cycle ${ }^{40}$. The reservoirs for WNV are wild birds, and many of them are long-distance migratory species. This is probably how the virus has spread so rapidly across the continental United States and into Canada and Mexico. Six years later, WNV could be found practically everywhere in North America ${ }^{40}$. Thus, the virus has been moving southwards across the Americas. It was detected in the Cayman Islands in 2001, in the island of Guadeloupe and in Mexico in 2002, and in El Salvador and Cuba in 2003 and 2004. In 2005, WNV reached South America and was detected in horses in Colombia that were found having neutralizing antibodies ${ }^{21}$. In 2006, WNV was isolated from the brains of two horses with encephalitis in Argentina (Levis S: personal communication, 2006).

The emergence of WNV in Brazil is highly likely, considering that many of the reservoir birds migrate from the Northern Hemisphere to Brazil. Brazil also has a huge variety of bird species including some that have previously been found to be WNV reservoirs, such as Passer domesticus, which is abundant in urban areas, alongside Culex mosquitoes ${ }^{21}{ }^{40}$. However, a serological survey of 5,000 wild birds from different Brazilian regions in 2004 did not detect animals infected by WNV (Araujo AA: personal communication, 2005).

The Oropouche virus causes outbreaks of acute febrile dengue-like illness including some meningitis cases. It was first isolated in 1955, from a febrile forest worker in Trinidad ${ }^{1}$. The first urban outbreak of OROV fever was reported in Belém (Brazil) in 1961, with approximately 11,000 cases. Subsequently, more than 30 outbreaks have been reported in the Amazon and Central Plateau regions, reaching in some cases up to 100,000 human infections. OROV has became the second most frequent arbovirus in terms of numbers of reported cases in Brazil, only supplanted by dengue. OROV fever outbreaks have also been reported in other countries, such as Panama in 1989 and Peru in 1992 $2^{37}$.

The original sylvan cycle of OROV includes sloths as reservoirs and Aedes serratus and Culex quinquefasciatus as vectors. Curiously, this virus has adapted to an urban epidemic cycle that involves man as the reservoir and Culicoides paraensis (Ceratopogonidae) as the vector ${ }^{37}$.

The Oropouche virus can mutate in nature and may also be responsible for new viruses such as the Jatobal virus, which was isolated in the Amazon Region from Nasua nasua. This virus, which has never been reported to infect man, has an S-RNA segment that is very similar to that of OROV and an M-RNA segment that is probably from another Simbu serogroup, Orthobunyavirus. Thus, the Jatobal virus is probably a natural mutant that originated by rearrangement of the OROV genome with that of another Orthobunyavirus ${ }^{26}$. This rearrangement mechanism might generate highly virulent mutants.

The Oropouche virus has also been found circulating outside of the Amazon region. In 2003, OROV was isolated from a Callithrix primate captured on the Brazilian Central Plateau, in the southeastern region, not far from large cities such as Belo Horizonte and Brasília (the capital of Brazil) ${ }^{23}$. Previously, in 1985, individuals presenting neutralizing antibodies for OROV were reported in the area. Moreover, OROV antibodies were also observed in two wild birds captured in the southern region (Araujo AA: personal communication, 2005). Considering that Culicoides paraensis is present in low-altitude areas of the whole country, as well as in most of the Americas, there is a risk of OROV emergence on the heavily populated northeastern and southeastern coasts of Brazil, thus causing epidemics ${ }^{10}$.

The ten arboviruses mentioned above have the potential to become important public health problems in Brazil over the coming years and deserve surveillance as part of effective control programs for humans and domestic animals. This surveillance needs to be able to detect the first cases of these emerging arboviruses, and rapid laboratory diagnosing of suspected cases followed by control measures is fundamental for this. Without a vigilant surveillance system, these pathogens could go unnoticed until they cause large outbreaks.

In cases of acute febrile illness outbreaks of MAYV, SLEV, CHIKV and OROV, laboratory diagnosing of suspected cases is fundamental because these viruses cannot easily be differentiated from other viral diseases, such as dengue, and may remain unknown.

Chikungunya virus surveillance should be carried out at Brazilian seaports and international airports, to search for suspect cases and eliminate imported mosquitoes.

West Nile virus in Brazil could remain silent because of crossimmune protection of native birds due to previous native flavivirus infection or because of lack of an enabling bridge vector that feeds on the blood of birds, humans and horses. The virus could produce a small number of human cases and remain undetected, or it could cause large human outbreaks and epizootics among horses. For early detection of the introduction of WNV, in addition to wild bird surveillance, efficient and active surveillance of central nervous system infections of humans and horses needs to be implemented throughout the country. SLEV, VEEV IC and EEEV may also produce human and horse meningoencephalitis and surveillance of central nervous system infections, in both species, is necessary to detect these viruses. ROCV deserves surveillance for human meningoencephalitis only.

Aedes aegypti control is important for combating the urbanization of YFV. However, Aedes aegypti control has not been very successful in many parts of the country. Thus, the reason why YFV has not become reurbanized in Brazil may be the high level of immunized people acting as a barrier. However, it is important to continuously vaccinate, especially for children, in order to obtain complete protection against YFV for next generation of Brazilians.

Finally, the threat of outbreaks of ROCV, SLEV and WNV should stimulate the development of a broad-reactive Japanese encephalitis complex vaccine that offers protection in relation to all these viruses. 


\section{ACKNOWLEDGEMENT}

To Dr Colleen Jonsson for review of the manuscript.

\section{REFERENCES}

1. Anderson CR, Spence I, Downs WG, Aitken THG. Oropouche virus: a new human disease agent from Trinidad, West Indies. The American Journal of Tropical Medicine and Hygiene 10:574-578, 1961.

2. Brandão PE, Freitas PHB, Oliveira MVS, Jerez JA, Carrieri ML, Kotait I. Detection of Eastern Equine Encephalitis Virus (Togaviridae, Alphavirus) in an outbreak of encephalitis in horses. In: Abstracts of the Brazilian Society for Virology Annual Meeting, Florianopolis. Virus Reviews and Research 8 (suppl 1):124, 2003.

3. Brault AC, Powers AM, Chavez CL, Lopez RN, Cachon MF, Gutierrez LF, Kang W, Tesh RB, Shope RE, Weaver SC. Genetic and antigenic diversity among eastern equine encephalitis viruses from North, Central and South America. The American Journal of Tropical Medicine and Hygiene 61:579-586, 1999.

4. Brault AC, Powers AM, Ortiz D, Estrada-Franco JG, Navarro-Lopez R, Weaver SC. Venezuelan equine encephalitis emergence: Enhanced vector infection from a single amino acid substitution in the envelope glycoprotein. Proceedings of the National Academy of Sciences of USA 101: 11344-11349, 2004.

5. Chambers TJ, Hahn CS, Galler R, Rice CM. Flavivirus genome organization, expression and replication. Annual Reviews of Microbiology 44:649-688, 1990

6. Chang GJ, Cropp CB, Kinney RM, Trent DW, Gubler DJ. Nucleotide sequence variation of the envelope protein gene identifies two distinct genotypes of yellow fever virus. Journal of Virology 69:5773-5780, 1995.

7. Coimbra TLM, Santos CLS, Rocco IM, Petrella SMCN, Nagamori AH, Marti AT, Santos RN, Fialho DM, Lavigne S, Buzzar M, Suzuki A. Mayaro Virus: three imported cases in São Paulo. In: Abstracts of the Brazilian Society for Virology Annual Meeting, Salvador. Virus Reviews and Research 10 (suppl 1):150, 2005 .

8. Crochu S, Cook S, Attoui H, Charrel RN, De Chesse R, Belhouchet M, Lemasson J-J, De Micco P, Lamballerie X. Sequences of flavivirus-related RNA viruses persist in DNA form integrated in the genome of Aedes spp. Mosquitoes. Journal of General Virology 85:1971-1980, 2004

9. DeFilippis VR, Villareal LP. Virus evolution. In: Knipe DM, Howley PM (eds) Fields Virology. Lippincott Williams \& Wilkins, Philadelphia, p. 353-370, 2001.

10. Felippe-Bauer ML, Cáceres AG, Silva CS, Valderrama-Bazan W, Gonzáles-Perez A. Two new Culicoides of the paraensis species group (Diptera: Ceratopogonidae) from the Amazonian region of Peru. Memórias do Instituto Oswaldo Cruz 98:1051-1058, 2003.

11. Fernandez Z, Moncayo AC, Carrara AS, Forattini OP, Weaver SC. Vector competence of rural and urban strains of Aedes (Stegomyia) albopictus (Diptera: Culicidae) from Sao Paulo State, Brazil for IC, ID, and IF subtypes of Venezuelan equine encephalitis virus. Journal of Medical Entomology 40:522-527, 2003.

12. Figueiredo LT, Rosa APAT, Fiorillo AM. Níveis de anticorpos para arbovírus em indivíduos da Região de Ribeirão Preto, SP (Brasil). Revista de Saúde Pública 20:204-211, 1986.

13. Figueiredo LTM, Nogueira RMR, Cavalcanti SMB, Rosa APT, Schatzmayr H. Study of two different enzyme immunoassays for the detection of Mayaro virus antibodies. Memórias do Instituto Oswaldo Cruz 84:303-307,1989.

14. Franco 0. História da Febre Amarela no Brasil. Ministério da Saúde, Rio de Janeiro, 1969.

15. Halstead SB. Emergence mechanisms in yellow fever and dengue. In: Scheld WM, Craig WA, Hugues JM (eds) Emerging Infections, ASM, Washington, p. 65-79, 1998

16. Iversson LB, Rosa APAT, Rodrigues SG, Rosa MDB. Human disease caused by Venezuelan Equine Encephalitis subtype IF in Ribeira Valley, São Paulo, Brazil. In:Abstract of Annual Meeting of the American Society of Tropical Medicine and Hygiene, New Orleans, USA, p. 143, 1990.
17. Iversson LB, Tiriba AC. Encefalite por arbovírus Rocio. In: Veronesi R, Focaccia R (eds) Tratado de Infectologia, Atheneu, São Paulo, p. 233-239, 1997.

18. Junt T, Heraud JM, Lelarge J, Labeau B, Talarmin A. Determination of natural versus laboratory human infection with Mavaro virus by molecular analysis. Epidemiology of Infections 123:511-513, 1999.

19. Kinney RM, Johnson BJB, Welch JB, Tsuchiya KR, Trent DW. The full-length nucleotide sequences of the virulent Trinidad donkey strain of Venezuelan equine encephalitis virus and its attenuated vaccine derivative, strain TC83. Virology 170: 19-31, 1989.

20. Lopes OS, Coimbra TLM, Sacchetta LA, Calisher CH. Emergence of a new arbovirus disease in Brazil. 1. Isolation and characterization of the etiologic agent, Rocio virus. American Journal of Epidemiology 107: 444-449, 1978.

21. Mattar S, Edwards E, Laguado J, Gonzalez M, Alvarez J, Komar N. West Nile virus antibodies in Colombian horses. Emerging Infectious Diseases 11: 1497-1498, 2005.

22. Meslin FX. Global aspects of emerging and potential zoonoses: a WHO perspective. Emerging Infectious Diseases 3: 223-228, 1997

23. Nunes MRT, Martins LC, Rodrigues SG, Chiang JO, Azevedo RSS, Travassos da Rosa APA, Vasconcelos PFC. Oropouche virus isolation, Southeast Brazil. Emerging Infectious Diseases 11:1610-1613, 2005.

24. Pinheiro FP, Freitas RB, Rosa JFT, Gabbay YB, Mello WA, Le Duc JW. An outbreak of Mayaro virus disease in Belterra, Brazil. I. Clinical and virological findings. The American Journal of Tropical Medicine and Hygiene 30:674-681,1981.

25. Rosa JFST, Rosa APAT, Vasconcelos PFC, Pinheiro FP, Rodrigues SG, Rosa EST, Dias LB, Cruz ACR. Arboviruses isolated in the Evandro Chagas Institute, including some described for the first time in the Brazilian Amazon region, their known hosts, and their pathology for man. In: Rosa APAT, Vasconcelos PFC, Rosa JFST (eds). An overview of arbovirology in Brazil and neighbouring countries. Instituto Evandro Chagas, Belém, p. 19-31, 1998.

26. Saeed MF, Wang H, Suderman M, Beasley DW, Rosa AT, Li L, Shope RE, Tesh RB Barrett $\mathrm{AD}$. Jatobal virus is a reassortant containing the small RNA of Oropouche virus. Virus Research 77:25-30, 2001.

27. Santos CL, Bisordi I, Petrella SM, Pereira LE, Souza RP, Coimbra TL, Bessa TA, Oshiro FM, Lima LB, Cerroni MP, Marti AT, Barbosa VM, Katz G, Suzuki A. St. Louis encephalitis virus: first isolation from a human in Sao Paulo State, Brazil. Revista do Instituto de Medicina Tropical de São Paulo 47:281-285, 2005.

28. Soper FL. Febre amarela silvestre. Novo aspecto epidemiológico da doença. Revista de Hygiene e Saúde Pública 10:107-144, 1936.

29. Straatmann A, Santos-Torres S, Vasconcelos PF, Rosa APT, Rodrigues SG, TavaresNeto J. Serological evidence of the circulation of the Rocio arbovirus (Flaviviridae) in Bahia. Revista da Sociedade Brasileira de Medicina Tropical 30:511-515, 1997.

30. Strauss JH, Strauss EG. Alphaviruses. Microbiology Reviews 58:491-562, 1994.

31. Tesh RB, Watts DM, Russell KL, Damodaran C, Calampa C, Cabezas C, Ramirez G, Vasquez B, Hayes CG, Rossi CA, Powers AM, Hice CL, Chandler LJ, Cropp BC, Karabatsos N, Roehrig JT, Gubler DJ. Mayaro virus disease: an emerging mosquito-borne zoonosis in tropical South America. Clinical and Infectious Diseases 28:67-73,1999.

32. Twiddy SS, Holmes EC. The extent of homologous recombination in members of the genus Flavivirus. Journal of General Virology 84:429-440, 2003.

33. Van der Stuyft P, Gianella A, Pinard M, Cespedes J, Lora J, Peredo C, Pelegrino JL, Vorndam V, Boelaert M. Urbanisation of yellow fever in Santa Cruz, Bolivia. Lancet 353:1558-1562, 1999 .

34. Vasconcelos PF. Yellow Fever. Revista da Sociedade Brasileira de Medicina Tropical 36:275-293, 2003

35. Vasconcelos PFC, Bryant JE, Rosa APAT, Tesh RB, Rodrigues SG, Barrett ADT Genetic divergence and dispersal of yellow fever virus. Emerging Infectious Diseases 10:1578-1584, 2004.

36. Vasconcelos PFC, Luna EJ, Galler R, Silva LJ, Coimbra TL, Barros VL, Monath TP, Rodigues SG, Laval C, Costa ZG, Vilela MF, Santos CL, Papaiordanou PM, Alves VA, Andrade LD, Sato HK, Rosa ES, Froguas GB, Lacava E, Almeida LM, Cruz AC, Rocco IM, Santos RT, Oliva OF. Serious adverse events associated with yellow fever 17DD vaccine in Brazil: a report of two cases. Lancet 358:91-97, 2001 
37. Vasconcelos PFC, Rosa APAT, Pinheiro FP, Shope RE, Rosa JFST, Rodrigues SG, Dégallier N, Travassos da Rosa ES. Arboviruses pathogenic for man in Brazil. In: Rosa APAT, Vasconcelos PFC, Rosa JFST (eds) An overview of arbovirology in Brazil and neighbouring countries, Instituto Evandro Chagas, Belém, p.72-99 1998.

38. Vogel P, Kell WM, Fritz DL, Parker MD, Schoiepp RJ. Early events in the pathogenesis of eastern equine encephalitis virus in mice. American Journal of Pathology 166:159-171, 2005.
39. Weaver SC, Ferro C, Barrera R, Boshell J, Navarro JC. Venezuelan equine encephalitis. Annual Review of Entomology 49:141-174, 2004.

40. West Nile Virus Activity - United States, January 1-December 1, 2005. Morbidity and Mortality Weekly Report 54:1253-1256,2005. 